\title{
Hub Device
}

National Cancer Institute

\section{Source}

National Cancer Institute. Hub Device. NCI Thesaurus. Code C49991.

An electronic device designed as a central connection for other devices. 